\title{
A PESQUISA COMO PRINCÍPIO PEDAGÓGICO NA EDUCAÇÃO PROFISSIONAL TÉCNICA DE NÍVEL MÉDIO PARA A CONSTITUIÇÃO DO SER SOCIAL E PROFISSIONAL
}

\section{LA INVESTIGACIÓN COMO PRINCIPIO PEDAGÓGICO EN LA EDUCACIÓN PROFESIONAL TÉCNICA DE NIVEL SECUNDARIO PARA LA CONSTITUCIÓN DEL SER SOCIAL Y PROFESIONAL}

\begin{abstract}
RESEARCH AS A PEDAGOGICAL PRINCIPLE IN PROFESSIONAL TECHNICAL EDUCATION OF SECONDARY LEVEL FOR THE CONSTITUTION OF THE SOCIAL AND PROFESSIONAL
\end{abstract} SUBJECT

Salete Valer* Ângela Brognoli** Laura Lima ${ }^{* * *}$ Instituto Federal de Educação, Ciência e Tecnologia de Santa Catarina, Campus Florianópolis-Continente

RESUMO: Os documentos oficiais lançados na última década para a Educação Básica têm reforçado a necessidade de uma educação politécnica e universal, propondo a pesquisa como princípio pedagógico, inclusive para a Educação Profissional Técnica de Nível Médio. Este artigo objetiva depreender quais práticas de letramento e tecnologias estão envolvidas nesse princípio, objetos de ensino dos componentes de Línguas (materna e adicionais). Buscou-se em BRASIL (2013), BRASIL (2015), Demo (2006, 2015), Martins (2009) e Rojo $(2005,2013)$ as bases documentais e teóricas para análise do objeto em estudo, tendo como enfoque metodológico a pesquisa documental. Os resultados indicam que os componentes curriculares de Línguas possuem papel fundamental em relação ao ensino do letramento envolvido na prática da pesquisa. Conclui-se que o letramento relativo às práticas investigativas e ao uso das tecnologias digitais devem ser utilizados como recursos pedagógicos também nos demais componentes curriculares, a fim de que a qualificação proposta seja ampliada nessa modalidade de educação.

PALAVRAS-CHAVE: Pesquisa científica. Educação Profissional Técnica de Nível Médio. Ensino de línguas.

\footnotetext{
* Doutora em Psicolinguística Aplicada (UFSC). Professora de Português do Instituto Federal de Educação, Ciência e TecnologiadeSanta Catarina (IFSC). Campus Florianópolis-Continente. E-mail:salete.valer@ifsc.edu.br

** Doutoranda em Estudos da Tradução (UFSC). Professora de Inglês do Instituto Federal de Educação, Ciência e Tecnologia de Santa Catarina (IFSC). Campus Florianópolis-Continente. E-mail: angela@ifsc.edu.br

*** Doutoranda em Linguística Aplicada (UFSC). Professora de Espanhol do Instituto Federal de Educação, Ciência e TecnologiadeSanta Catarina (IFSC). Campus Florianópolis-Continente. E-mail: laura.lima@ifsc.edu.br.
} 
RESUMEN: Los documentos oficiales publicados en la última década para la Educación General Básica reafirman la necesidad de una educación politécnica y universal, tomando como presupuesto la pesquisa como principio pedagógico incluso para la Educación Profesional Técnica de Nivel Secundario. En este artículo, se objetiva entender cuáles son las práctica de aprendizaje de lectoescritura y tecnologías implicadas en ese principio, ambos contenidos objeto de enseñanza en los componentes curriculares de idiomas (materno y extranjero). Se recurrió a BRASIL (2013); BRASIL (2015); Demo (2006, 2015); Martins (2009); Rojo (2005, 2013) para construir la base teórica para el análisis del objeto en estudio y se adoptó, como enfoque metodológico, la investigación documental. Los resultados indican que los componentes curriculares de idiomas desempeñan un papel fundamental en relación a la enseñanza del aprendizaje de lectoescritura implicado en prácticas de investigación. Se llega a la conclusión de que el aprendizaje de lectoescritura de las prácticas investigativas y las tecnologías digitales deben ser utilizados como recursos pedagógicos también en los demás componentes curriculares, de manera que se amplíe la formación propuesta en esa modalidad de educación.

PALABRAS CLAVE: Investigación Científica. Educación Profesional Técnica de Nivel Secundario. Enseñanza de Idiomas.

ABSTRACT: The official documents written in the last decade for Basic Education have reinforced the need for polytechnic and universal education. They propose research as a pedagogical principle, including in the Professional Technical Education of Secondary Level. This article aims to detect which literacy practices and technologies are involved in that principle, in the teaching object of the Languages (mother tongue and additional languages) disciplines. The theoretical basis for the analysis of the object under study relied on BRASIL (2013), BRASIL (2015), Demo (2006, 2015), Martins (2009) e Rojo (2005, 2013) among others, and utilized documentary research. The results indicate that the Languages disciplines have a fundamental role concerning literacy teaching involved in the research practice. It was concluded literacy related to investigative practices and the use of digital technologies should be used as pedagogical resources also in other disciplines of the courses, so that the proposed education may be effective in the modality of education discussed here.

KEYWORDS: Scientific research. Technical Professional Education of Secondary Level. Languages teaching.

\section{INTRODUÇÃO}

O plano para a educação nacional indicado na Constituição Federal de 1988 foi lançado em 1996, intitulado Leis de Diretrizes e Bases (LDB) (BRASIL, 1996). O título II deste documento trata dos princípios e fins da educação em âmbito nacional. Mais especificamente, o Art. $2^{\circ}$ propõe que "a educação, dever da família e do Estado, inspirada nos princípios de liberdade e nos ideais de solidariedade humana, tem por finalidade o pleno desenvolvimento do educando, seu preparo para o exercício da cidadania e sua qualificação para o trabalho”. Após a proposta inicial para a educação nacional e a sua aplicação nos contextos reais, muitas pesquisas e estudos foram realizados, cujos resultados geraram novos documentos com a finalidade de propor diretrizes para a qualificação da educação nacional.

Em um desses documentos, lançado pelo Ministério da Educação (BRASIL, 2013), estão definidas as Diretrizes Curriculares Nacionais Gerais da Educação Básica (DCNGEB), cujos objetivos buscam atualizar as políticas educacionais propostas na LDB. Para dar conta desse propósito, esse documento indica opções políticas, sociais, culturais e educacionais, enfatizando que a função da educação se fundamenta "[...] na cidadania e na dignidade da pessoa, o que implica igualdade, liberdade, pluralidade, diversidade, respeito, justiça social, solidariedade e sustentabilidade” (BRASIL, 2013, p. 19). O documento explicita o foco educativo que deve nortear cada uma das instâncias que constituem a Educação Básica (Educação Infantil, Ensino Fundamental e Ensino Médio) e enfatiza a necessidade de se promover a inclusão social e a formação de sujeitos cientes de seus direitos e deveres, comprometidos, assim, com a transformação de uma sociedade com qualidade social, mais justa e fraterna.

De volta à Lei de 1996, que já trata da relação entre Ensino Médio e qualificação para o trabalho, tem-se no Capítulo III o Art. 39, o qual dispõe que "a educação profissional, integrada às diferentes formas de educação, ao trabalho, à ciência e à tecnologia, conduz ao permanente desenvolvimento de aptidões para a vida produtiva". Acrescenta que "o aluno matriculado ou egresso do ensino fundamental, médio e superior, bem como o trabalhador em geral, jovem ou adulto, contará com a possibilidade de acesso à educação profissional". Na sequência do documento, o Art. 40 sinaliza que "A educação profissional será desenvolvida em 
articulação com o ensino regular ou por diferentes estratégias de educação continuada, em instituições especializadas ou no ambiente de trabalho" (BRASIL, 1996). Isso para que abranja o maior número possível de comunidades, a fim de promover, dessa maneira, a inclusão do sujeito no processo educativo e profissional.

Nessa realidade, a Educação Profissional Técnica de Nível Médio é uma modalidade de educação complementar ao Ensino Médio, a qual pode ser ofertada de forma integrada, concomitante ou subsequente. A instituição que oferta a educação profissional deve atentar para não ofuscar ou suprimir as práticas e os princípios ${ }^{1}$ relativos à formação geral das diferentes instâncias da Educação Básica, haja vista que são esses princípios educativos que fundamentam a Educação Profissional (BRASIL, 2013, p. 219, grifos nossos). De forma sintética, são estes os princípios: educação para a qualidade social; o trabalho, a ciência, a tecnologia e a cultura como dimensões da formação humana; o trabalho como princípio educativo; a abordagem dos conteúdos por projetos temáticos; a pesquisa como princípio pedagógico; o domínio da tecnologia de informação e comunicação ${ }^{2}$. Dessa forma, todos esses princípios devem alicerçar as práticas educativas no processo de escolarização tanto para a formação geral como para a formação profissional.

Em acréscimo, o Catálogo Nacional para Cursos Técnicos (CNCT) de Educação Profissional Técnica de Nível Médio, lançado pelo Ministério da Educação, esclarece que o curso técnico é

[...] um curso de nível médio que objetiva capacitar o aluno com conhecimentos teóricos e práticos nas diversas atividades do setor produtivo. Acesso imediato ao mercado de trabalho é um dos propósitos dos que buscam este curso, além da perspectiva de requalificação ou mesmo reinserção no setor produtivo. (BRASIL, 2012, p. 149 , grifos nossos)

Com base no que está apresentado no respectivo catálogo, observa-se que é objetivo dessa modalidade de educação desenvolver no estudante a capacidade de lidar com os aspectos que envolvem a teoria do objeto de ensino. Isso significa dizer que a instituição deve mediar a construção do conhecimento sobre o quadro teórico-metodológico do objeto em estudo. Esse saber fornece as condições necessárias à ampliação da capacidade para a prática do objeto de aprendizagem, levando, assim, o estudante a uma prática reflexiva e criativa e não meramente executora.

Em outras palavras, quando se fala em Educação Profissional Técnica de Nível Médio, em quaisquer das suas formas de oferta, a formação geral do aluno deve se tornar inseparável da formação profissional e vice-versa. Para isso deve-se enfocar o trabalho como princípio educativo, a fim de superar "[...] a dicotomia historicamente cristalizada da divisão social do trabalho entre a ação de executar e as ações de pensar, planejar, dirigir, supervisionar ou controlar a qualidade dos produtos ou serviços." (BRASIL, 2013, p. 207). Com isso, incorpora-se a dimensão intelectual ao trabalho produtivo e vice-versa, buscando, destarte, a formação de trabalhadores capazes de atuar democraticamente como cidadãos, na posição de dirigentes ou de subordinados.

Essa dicotomia entre ensino tecnicista para as classes desfavorecidas socioeconomicamente e educação propedêutica para as classes abastadas, historicamente existente, deve ser rompida nas diferentes instâncias educativas pela adoção da pesquisa como princípio pedagógico (BRASIL, 2013, p. 19). Esse princípio pedagógico é o meio pelo qual a instituição de ensino oferece as condições necessárias e adequadas para que o estudante, em qualquer modalidade e nível da Educação Básica atinja o acesso-permanênciasucesso-progressão no decorrer do seu processo educativo. Isso significa dizer que a pesquisa como prática social, objeto de ensino e aprendizagem no processo de escolarização, tem por fim desenvolver nos estudantes habilidades cognitivas para interpretar teorias, relacionar, analisar, criticar, refletir, rejeitar ideias fechadas, aprender, buscar soluções, propor alternativas etc. Esses conhecimentos constituídos pela linguagem se materializam por textos específicos em decorrência da sua função social. Esses saberes contribuem para que o sujeito tenha sucesso no processo de aprendizagem e tenha as condições necessárias para progredir também nos estudos e não somente no trabalho. Assim, observa-se a relevância do aprendizado desse princípio no processo de escolarização.

\footnotetext{
${ }^{1}$ Esses princípios estão apresentados em DCNGEB (BRASIL, 2013, p. 179).

${ }^{2}$ Destaca-se a relevância de todos esses princípios para a qualidade da educação, porém, por questões de espaço, este artigo tratará dos seguintes princípios: a pesquisa como princípio pedagógico e o domínio da tecnologia da comunicação.
} 
Diante do exposto, o objeto desta pesquisa é o entendimento da relação existente entre a pesquisa como princípio pedagógico que deve ser adotado no processo de ensino e aprendizagem na formação da Educação Profissional Técnica de Nível Médio, conforme as DCNGEB, e os campos de experiências ${ }^{3}$ definidos como Práticas investigativas e Práticas culturais das tecnologias de informação e comunicação presentes no documento Base Nacional Comum Curricular (BRASIL, 2015²). Isso porque o ensino relativo aos processos comunicativos inseridos em tais campos de experiências é de responsabilidade principalmente dos componentes curriculares da área das Línguas (Linguagens), enquanto a adoção da prática da pesquisa como princípio pedagógico pode ocorrer em todos os componentes curriculares. Busca-se, pois, relacionar esses diferentes saberes com o fim de qualificar o processo pedagógico.

Nesse contexto, o problema a ser investigado é a aplicabilidade da pesquisa como princípio pedagógico no processo de formação da Educação Profissional Técnica de Nível Médio e o papel dos componentes curriculares de Linguagem nos esforços para viabilizar tal aplicabilidade. O pressuposto para este problema é o de que as relações existentes entre os usos sociais da linguagem e a prática da pesquisa como princípio pedagógico precisam ser mais bem entendidas, a fim de que haja um melhor aproveitamento no processo de ensino e aprendizagem na educação profissional, gerando, desse modo, um aproveitamento maior do tempo e do espaço de escolarização.

Em decorrência do problema apresentado, o objetivo geral desta pesquisa é identificar quais práticas de linguagem fazem parte da pesquisa como princípio pedagógico. Pretende-se, particularmente, discutir de que forma essa atividade está relacionada aos campos de experiências Práticas investigativas e Práticas culturais das tecnologias de informação e comunicação que devem ser desenvolvidas no decorrer da Educação Profissional para que o estudante alcance o acesso-permanência-sucesso-progressão. Para atingir o objetivo geral, os objetivos específicos são: a) ler individualmente os documentos oficiais; b) sistematizar os aspectos relativos à pesquisa como princípio pedagógico; c) sistematizar os saberes pertinentes à área da Linguagem que devem nortear o processo de ensino e aprendizagem da Educação Profissional no que diz respeito ao objeto em estudo; d) relacionar o que está posto em (b) e (c) para a discussão do pressuposto da pesquisa. Essas ações nortearão, portanto, o processo desta investigação.

Esta pesquisa se justifica pela necessidade de que sejam mais bem entendidos tais saberes que norteiam o processo de ensino e aprendizagem da língua(gem), seja como língua materna ${ }^{5}$, seja como línguas adicionais ${ }^{6}$ (Espanhol, Inglês ${ }^{7}$ ). Esse entendimento torna-se relevante, pois, com as informações sistematizadas, os docentes da área poderão contribuir de forma mais efetiva na elaboração de procedimentos mais eficazes para o ensino em todos os componentes curriculares, haja vista que a constituição do saber se dá por meio da língua e se materializa por meio de gêneros discursivos/textuais, conforme referencial teórico. Logo, ressaltase a relevância de se qualificar esses processos de acordo com as novas teorias que envolvem o objeto em estudo.

Para dar conta do propósito, este artigo se organiza nas seguintes seções: em (1), Introdução, estão apresentados o tema, o objeto, o problema, o pressuposto e a justificativa; em (2), Referencial teórico, estão expostos os conteúdo relativos à pesquisa como princípio pedagógico (BRASIL, 2013; DEMO, 2006, 2015; MARTINS, 2009); às tecnologias de informação e comunicação (BRASIL, 2013; GARCIA, 2009; ROJO, 2005, 2013) e à linguagem nas práticas investigativas (BRASIL, 2015; VALER, 2016a, 2016b); em (3),

\footnotetext{
${ }^{3}$ De acordo com o documento BNCC (BRASIL, 2015, p. 20), campos de experiências são "[...] conjuntos formados considerando alguns pontos de convergência entre os elementos que os orientam. [...] Incluem determinadas práticas sociais e culturais de uma comunidade e as múltiplas linguagens simbólicas que nelas estão presentes".
}

${ }^{4}$ Este documento, lançado em 2015 pelo MEC, sobre o qual trataremos no referencial teórico e na metodologia, está ainda em audiência pública.

${ }^{5} \mathrm{O}$ IFSC possui um campus bilíngue, mas não trataremos de exemplos das LIBRAS neste trabalho.

${ }^{6}$ Prefere-se adotar aqui o termo Língua Adicional e não Língua Estrangeira, pois, acredita-se, assim como Schlatter e Garcez (2009), que o termo Língua Adicional sinaliza para uma escolha feita pela pessoa em adicionar mais uma língua ao seu repertório. Nas palavras dos autores: "[...] falar de uma língua adicional em vez de uma língua estrangeira enfatiza o convite para que os educandos (e educadores) usem essas formas de expressão para participar na sua própria sociedade. [...] esse convite envolve também a reflexão sobre que língua é essa, de quem ela é e de quem pode ser, a que ela serve, o que cada um tem a ver com ela." (SCHLATTER; GARCEZ, 2009, p. 127).

${ }^{7}$ Deixa-se de fora deste artigo o ensino de Português como língua estrangeira pelo fato de essa modalidade de ensino não estar na BNCC (BRASIL, 2015), além de ainda não fazer parte do ensino da área de Linguagens deste Campus, onde a pesquisa está sendo desenvolvida. 
Metodologia, o espaço está destinado à apresentação das modalidades, procedimentos e instrumentos da pesquisa; em (4), Análise e discussão, faz-se a relação entre as variáveis da pesquisa e o referencial teórico, e, por fim, em (5), Considerações finais, retoma-se o objetivo e o pressuposto da pesquisa para o fechamento do texto.

\section{REFERENCIAL TEÓRICO}

Esta seção está organizada nas seguintes subseções: (2.1) A pesquisa como princípio pedagógico; (2.2) As tecnologias de informação e comunicação; (2.3) A linguagem nas práticas investigativas.

\subsection{A PESQUISA COMO PRINCÍPIO PEDAGÓGICO}

As instituições de ensino formais vêm perdendo ao longo do tempo seu monopólio na transmissão do conhecimento, principalmente a partir das novas tecnologias. Para Demo (2015), a instrumentalização eletrônica em geral possibilita o contato cada vez maior com livros, bibliotecas e bancos de dados, o que torna o acesso ao conhecimento cada vez mais descentralizado. Diante desse novo panorama, é fundamental pensar sobre o papel das instituições e de seus professores no desenvolvimento da autonomia de aprendizagem dos alunos. Pesquisadores como Demo (2006, 2015) e Martins (2009) propõem a pesquisa como caminho didático e investigativo para atingir independência intelectual e, assim, poder atuar na condição de sujeito capaz de pensar por si e de (re)construir conhecimentos. Para Martins (2009, p. 39), o trabalho com pesquisa possibilita que o aluno deixe de ser "[...] ouvinte repetidor de conteúdos e passe a agir e a refletir com consciência crítica diante dos fatos estudados". Trata-se de uma proposta que visa à efetivação do protagonismo do estudante no seu próprio processo de aprendizagem, capaz, portanto, de levar o protagonismo também nos ambientes de trabalho e em demais ambientes de interação social.

Recentemente, documentos orientadores do ensino na Educação Básica, como as Diretrizes Curriculares Nacionais Gerais da Educação Básica (DCNGEB) (BRASIL, 2013) e a Base Nacional Curricular Comum (BNCC) (BRASIL, 2015) ampliaram o enfoque na pesquisa como princípio pedagógico, indo ao encontro do reconhecimento de que educar pela pesquisa é uma prática considerada como uma "necessidade da cidadania moderna" (DEMO, 2015, p. 3), direcionando o ensino, pois, para uma formação politécnica. Nesse aspecto, o documento DCNGEB (BRASIL, 2013, p. 218) especifica a pesquisa como princípio pedagógico, definida como uma atividade escolar, orientada e motivada pelos professores, que

[...] implica na identificação de uma dúvida ou problema, na seleção de informações de fontes confiáveis, na interpretação e elaboração dessas informações e na organização e relato sobre o conhecimento adquirido. [...] a prática de pesquisa propicia o desenvolvimento da atitude científica, o que significa contribuir, entre outros aspectos, para o desenvolvimento de condições de, ao longo da vida, interpretar, analisar, criticar, refletir, rejeitar ideias fechadas, aprender, buscar soluções e propor alternativas, potencializadas pela investigação e pela responsabilidade ética assumida diante das questões políticas, sociais, culturais e econômicas.

Nessa proposta, a atividade que envolve a pesquisa, quando organizada por meio de projetos contextualizados e articulados, torna a aprendizagem mais significativa, qualificando, assim, o processo de aprendizagem dos sujeitos estudantes.

Em relação a esse princípio pedagógico, ressalta-se que é comum o argumento de que, pela complexidade cognitiva e linguística que a caracteriza, a atividade de pesquisa deva ser realizada apenas na esfera acadêmica, ou seja, nos cursos superiores. Ocorre que a proposta para a qualificação da educação nacional que tem sido articulada pelos pensadores progressistas aqui apresentados, entre tantos outros, envolve que essa prática seja estendida também à esfera escolar, ou seja, à Educação Básica. Nessa perspectiva, enfatizase a importância do processo de mediação para o aprendizado desse conteúdo, pois, de acordo com os pressupostos teóricos sociointeracionistas de Vygotsky $(2008[1930])^{8}$, o desenvolvimento do pensamento e da linguagem tem origem social como

${ }^{8} \mathrm{O}$ aspecto cognitivo da aprendizagem da linguagem está indicado nas diretrizes para Educação Básica, haja vista que "O caráter sociointeracionista da linguagem verbal aponta para uma opção metodológica de verificação do saber linguístico do aluno, com o ponto de partida para a decisão daquilo que será desenvolvido, tendo como referência o valor da linguagem nas diferentes esferas sociais" (BRASIL, 2000, p. 18). 
consequência do processo de interação. Nessa teoria, a linguagem é atividade constitutiva do conhecimento de mundo em que o indivíduo se constrói como sujeito, dependendo de como será essa interação com o meio social, mediado pelo outro. Vê-se que essa nova proposta de ensino implica na ampliação dos conteúdos de aprendizagem para os sujeitos da esfera escolar, sendo necessário, portanto, o adequado processo de mediação para que sejam alcançados os propósitos apontados.

Em um mundo de sucessivas transformações, de mobilidade de pessoas, culturas e tecnologias, o fornecimento de informações não é mais a prática mais relevante a se desenvolver nas instituições de ensino, pois é possível acessar cada vez mais informações de forma diversificada e ampla fora das instituições. Por essa razão, esse documento sublinha a importância do papel dos professores e das instituições como mediadores para que os estudantes desenvolvam a capacidade de buscar informações e analisá-las para responder a perguntas relevantes, bem como a capacidade de pesquisar para (re)construir conhecimentos. Nesse novo contexto sociocultural e tecnológico, a curiosidade e a inquietude geradas pela oferta ilimitada de informação que se dá no mundo real que está posto na contemporaneidade podem ser mais bem aproveitadas quando se tem acesso aos conhecimentos desenvolvidos através da prática da pesquisa. A busca por saberes, sejam do senso comum, escolares ou científicos, sob aporte metodológico e teórico adequado, viabilizam respostas e proposições de alternativas para problemas verdadeiros da realidade do aluno, do seu ambiente de trabalho, da sua instituição de ensino e da comunidade onde está inserido. Todos esses saberes ampliam, dessa maneira, as possibilidades cognitivas e sociais dos sujeitos inseridos em contextos bem organizados para esse fim.

Ao se tratar da Educação Profissional Técnica de Nível Médio, a Resolução n. 6, de 20 de setembro de 2012 (BRASIL, 2012), no Capítulo II, Item III, aponta a relevância dos conhecimentos e habilidades da formação geral do Ensino Médio para subsidiar a educação profissional, sendo que, no Art.14, o item VI destaca que o conteúdo da "[...] tecnologia da informação, [...] e da iniciação científica [...]" (p. 5) devem permear o processo de ensino e aprendizagem dos cursos técnicos. Isso porque, de acordo com o Art. 21 da mesma resolução, “A prática profissional, prevista na organização curricular do curso, deve estar continuamente relacionada aos seus fundamentos científicos e tecnológicos, orientada pela pesquisa como princípio pedagógico que possibilita ao educando enfrentar o desafio do desenvolvimento da aprendizagem permanente." (BRASIL, 2012, p. 6).

As aplicações do conhecimento proposto por essas práticas pedagógicas vão além do processo de escolarização, propiciando, dessa forma, saberes que são utilizados para a prática da cidadania.

Ainda em relação ao aspecto pedagógico, o Parágrafo $1^{\circ}$ ressalta que a prática na Educação Profissional “[...] compreende diferentes situações de vivência, aprendizagem e trabalho, como experimentos e atividades específicas em ambientes especiais, tais como [...] projetos de pesquisa e/ou intervenção, visitas técnicas, simulações, observações e outras” (p.7). Por fim, no Item V, o documento reforça os princípios educativos presentes na formação geral, reiterando a necessidade de que sejam aplicados na educação profissional, situação em que

[...] organização curricular flexível, por disciplinas ou componentes curriculares, projetos, núcleos temáticos ou outros critérios ou formas de organização, desde que compatíveis com os princípios da interdisciplinaridade, da contextualização e da integração entre teoria e prática, no processo de ensino e aprendizagem (BRASIL, 2012, p. 7).

Essas informações reforçam a necessidade de que sejam utilizadas práticas linguísticas efetivas para a sistematização dos conhecimentos teóricos que, aplicados à prática, viabilizam uma reflexão sobre a realidade, formando, destarte, sujeitos mais críticos e ativos socialmente.

No documento DCNGEB (BRASIL, 2013) há uma seção específica que trata das Diretrizes Curriculares Nacionais para a Educação Profissional Técnica de Nível Médio, cujas orientações destacam que "[...] é necessário que a pesquisa como princípio pedagógico esteja presente em toda a educação escolar dos que vivem/viverão do próprio trabalho" (BRASIL, 2013, p. 218). Mais do que nunca, as instituições de educação profissional têm o grande desafio de formar profissionais autônomos capazes de resolver problemas de diversos níveis enfrentados pela sociedade e relacionados às suas áreas específicas de atuação. Trata-se de um desafio de grande impacto social o de proporcionar formação técnica e tecnológica comprometida com a aplicação do conhecimento em prol da 
melhoria da qualidade de vida de toda a sociedade, e, consequentemente, não uma formação tecnocrata e replicadora.

\subsection{AS TECNOLOGIAS DE INFORMAÇÃO E COMUNICAÇÃO}

Ao entender tecnologia como produto de conhecimentos sociais e culturais postos em prática por meio de técnicas para criar e recriar a realidade, recriando e remodelando a mesma sociedade que a produz (LÉVY, 2010), pode-se também entender as Tecnologias da Informação e da Comunicação (TIC) como um conceito mais amplo, conforme o fazem os Parâmetros Curriculares Nacionais (PCN), de 1998. Nesse documento, as TIC compreendem "[...] os diferentes meios de comunicação (jornalismo impresso, rádio e televisão), os livros, os computadores etc." (BRASIL, 1998, p. 135), de forma que é possível dividir as TIC utilizadas no processo educativo como analógicas ou digitais. Assim sendo, todas essas tecnologias podem fazer parte do conteúdo de ensino e aprendizagem da área de Linguagens.

Dentre as analógicas, têm-se recursos já amplamente utilizados nas salas de aula, como o giz, o quadro negro, o livro didático, a caneta e até mesmo a linguagem e as próprias instituições de ensino. Para fins deste trabalho, refere-se aqui às TIC com foco nas digitais, também chamadas de Novas TIC por alguns autores. Segundo Rojo (2013), é possível citar como exemplo jornais e revistas digitais, blogs, wiki, fanfics, ferramentas de escrita colaborativa, podcast, clips, games, fotolog, videologs, remixes, redes sociais (Facebook, Twitter), ambientes educacionais (AVA, portais etc.). Em um mundo cada vez mais digital, é preciso que as instituições de ensino se responsabilizem por preparar as pessoas de forma a torná-las aptas para "[...] buscar no ciberespaço um lugar para se encontrar, de maneira crítica, com diferenças e identidades múltiplas” (ROJO, 2013, p. 7). Vê-se que são crescentes os espaços digitais onde cada vez mais a interação humana se dá, são cenários de novas práticas sociais a partir de colisões de linguagens e culturas, portanto, é necessário que façam parte da aprendizagem na escolarização.

Ainda em relação ao tema, o acesso a esses espaços e práticas deve ser constantemente problematizado e discutido, no intuito de garantir sua autoria múltipla, multilíngue e multicultural de forma generalizada, ou seja, também por aqueles que não participam dos grupos de poder (GARCIA, 2009). É consenso que, através das novas tecnologias, deu-se a oportunidade de acessar o que antes era de domínio apenas das minorias social e economicamente dominantes. Contudo, o aproveitamento efetivo dessas oportunidades e mesmo a sobrevivência em contextos nos quais as TIC são essenciais só é possível com o domínio real dessas tecnologias. O desenvolvimento dos conhecimentos relacionados às TIC, considerado papel das instituições de ensino, precisa, desse modo, também caminhar ao lado de políticas públicas de acesso ao mundo digital.

No Brasil, segundo as duas edições do relatório apresentado pelo Comitê Gestor da Internet no Brasil (CGI), que têm como objetivo divulgar resultados de pesquisas sobre o uso das tecnologias de informação e comunicação nos domicílios brasileiros, o avanço do uso da internet pela população brasileira é flagrante, tendo aumentado de 37 milhões de usuários, em 2005 (CGI, 2010) para, aproximadamente, 94 milhões em 2014 (CGI, 2014). No entanto, se comparados os percentuais de indivíduos brasileiros com acesso à internet sobre o total de indivíduos, a diferença entre os que residem em áreas urbanas e rurais é gritante. Enquanto 59\% da população que reside em áreas urbanas têm acesso à internet, o mesmo acontece com apenas $29 \%$ da população de áreas rurais. A desigualdade aumenta ainda mais quando comparados os indivíduos pertencentes às classes $\mathrm{Ae} \mathrm{De} \mathrm{E}$, nas quais o percentual sobre o total de indivíduos é de $96 \%$ e 21\%, respectivamente. Esses aspectos indicam, portanto, a relevância das instituições de ensino das tecnologias no processo de escolarização.

Quanto ao uso das tecnologias em si, o relatório expõe que as principais TIC utilizadas são aquelas para enviar mensagens instantâneas, como aplicativos de mensagens, podcasts, com 83\% do total de usuários da internet, seguidas das utilizadas para participar de redes sociais, como Facebook, Google+, com 76\% do total de usuários. Além dessas, ainda aparecem no relatório outras TIC de compartilhamento de textos, imagens e vídeos, como e-mail, blogs, wikis, portais de notícias, fotologs, radioblogs, videologs, provedores de filmes via streaming, ferramentas de pesquisa e comparação de produtos e serviços, portais educacionais e de serviços públicos. Os resultados desse relatório podem ajudar, assim, a fundamentar o quanto é necessário e fundamental ainda a discussão sobre estratégias de inclusão por meio de ensino através de TIC. 
As TIC que aparecem no relatório do CGI, além de exploradas pelas instituições de ensino desde uma perspectiva de formação pessoal e cidadã, também precisam ser tratadas na perspectiva da formação profissional, visto que elas estão cada vez mais presentes nas práticas sociais do mundo do trabalho. Nessa relação, Kalantzis e Cope (2006) chamam a atenção para o fato de que, na contemporaneidade, espera-se que o trabalhador seja autônomo e multicapacitado, o que implica uma formação plural e cada vez mais crítica, permeada, dessa maneira, pelas tecnologias acima apresentadas.

Diante dessa realidade, é preciso pensar a educação e o ensino de línguas na Educação Profissional, bem como na Educação de forma geral, levando em consideração as TIC como ponto central, considerando, inclusive, que seu domínio é fundamental para que a pesquisa possa concretizar-se como princípio pedagógico, conforme discutido anteriormente.

\subsection{A LINGUAGEM NAS PRÁTICAS INVESTIGATIVAS}

A área de Linguagens se constitui pelos componentes curriculares de Língua Portuguesa, Línguas Adicionais, Arte e Educação Física. Para Celani et al. (2005), a linguagem desempenha papel fundamental nas trocas e interações sociais, princípios esses que norteiam os diversos documentos oficiais, entre os quais estão DCNGEB (BRASIL, 2013) e a BNCC (BRASIL, 2015).

Essa área tem o papel de desenvolver no educando, na Educação Básica, conhecimentos que lhes assegurem o domínio do letramento, que diz respeito à condição de "[...] participar das mais diversas práticas sociais permeadas pela escrita, abrange a construção de saberes múltiplos que permitam aos/às estudantes atuarem nas modernas sociedades tecnológicas, cada vez mais complexas também em relação às suas formas de comunicação" (BRASIL, 2015, p. 29). Além desse aspecto, a área contempla também vivências artísticas, literárias e corporais, que permitem a expansão do estudante por meio do contato com culturas locais e universais, enfatizando o multiculturalismo e o plurilinguismo, especialmente veiculados pelas modernas tecnologias. Nesse sentido, o multiletramento ${ }^{9}$ torna-se fator relevante para a formação plena e o caráter reflexivo das práticas de linguagens, as quais proporcionam ao educando inúmeras possibilidades de interação com outras formações culturais e tecnologias, aprimorando, por isso, a sua formação humana e profissional.

Nessa área, os componentes curriculares relativos às línguas (Língua Portuguesa e Línguas Adicionais) têm seus conteúdos de ensino articulados em cinco eixos, de acordo com as práticas e os conhecimentos de linguagem: sistema alfabético ortográfico e tecnologias de escrita, leitura, escrita e análise linguística, sendo este último transversal aos demais eixos. (BRASIL, 2015). Ao tratarse do objeto de estudo desta pesquisa, destaca-se o eixo da escrita, sem se desejar diminuir a relevância dos demais eixos pela própria transversalidade que os constitui. Nessa perspectiva, os objetivos de aprendizagem da língua escrita envolvem:

1) reflexões sobre as situações sociais em que se escrevem textos, para o desenvolvimento da valorização da escrita e a ampliação de conhecimentos sobre as práticas de linguagem nas quais a escrita está presente; 2) desenvolvimento de estratégias de planejamento, reescrita, revisão e avaliação dos textos, considerando-se a sua adequação às variedades linguísticas; 3 ) reflexões sobre os gêneros textuais 10 adotados nas situações de escrita, considerando-se os aspectos sociodiscursivos, temáticos, composicionais e estilísticos; 4) reflexões sobre os recursos linguísticos empregados nos textos, considerando-se as convenções da escrita e as estratégias discursivas planejadas em função das finalidades pretendidas (BRASIL, 2015, p. 40).

\footnotetext{
${ }^{9}$ Ao tratar do termo multiletramento, os documentos oficiais indicam que "[...] o que se defende, portanto, é a absoluta necessidade de se avocar e levar adiante o desafio de criar condições para que os alunos construam sua autonomia nas sociedades contemporâneas - tecnologicamente complexas e globalizadas - sem que, para isso, é claro, se vejam apartados da cultura e das demandas de suas comunidades. Isso significa dizer que a escola que se pretende efetivamente inclusiva e aberta à diversidade não pode ater-se ao letramento da letra, mas deve, isso sim, abrir-se para os múltiplos letramentos, que, envolvendo uma enorme variação de mídias, constroem-se de forma multissemiótica e híbrida - por exemplo, nos hipertextos na imprensa ou na internet, por vídeos e filmes, etc. Reitera-se que essa postura é condição para confrontar o aluno com práticas de linguagem que o levem a formar-se para o mundo do trabalho e para a cidadania com respeito pelas diferenças no modo de agir e de fazer sentido" (BRASIL, 2006, p. 29).

${ }^{10}$ Neste artigo, pelo seu enfoque documental, não serão apresentadas as teorias que tratam do termo gênero como discurso e gênero como materialidade linguística, conforme discussão proposta por Rojo (2005). Nesse sentido, quando necessário, usar-se-á o termo gênero discursivo/textual para abranger os dois aspectos.
} 
Ao entender-se que a atividade de escrita se constitui materialmente pelos demais eixos da língua, ressalta-se, portanto, o papel da escola como a principal agência de mediação desse aprendizado.

O conteúdo para o ensino da língua portuguesa e das línguas adicionais está organizado em cinco campos de experiências. A BNCC (BRASIL, 2015, p. 41) destaca que "Consonante a uma concepção de língua como forma de interação entre os sujeitos, a organização dos objetivos de aprendizagem [...] considera, além das práticas de linguagem, os campos de atuação nos quais elas se realizam. A proposição de campos de atuação aponta para a importância da contextualização do conhecimento”.

Observa-se que as práticas de linguagem que devem ser desenvolvidas no contexto de escolarização básica estão distribuídas em: Práticas da vida cotidiana, Práticas artístico-culturais, Práticas político-cidadãs, Práticas investigativas, Práticas culturais das tecnologias de informação e comunicação. Para o Ensino Médio, o documento aborda também Práticas do mundo do trabalho, sendo que esse campo está direcionado ao ensino de textos relativos à redação técnica. Acrescenta-se a esse campo textos que tratam das práticas da linguagem voltada a cada área (curso) específica de formação profissional.

Neste artigo, destaca-se o conteúdo dos campos de experiência das práticas investigativas e das práticas culturais das tecnologias de informação e comunicação, a fim de construir uma relação com a prática da pesquisa como princípio pedagógico. No item anterior, já foram discutidos aspectos pertinentes às práticas de comunicação e informação, por essa razão passa-se aos aspectos das práticas investigativas.

O campo de experiência práticas investigativas, pertencente à área de Línguas, define as práticas de letramento que desenvolvem mais diretamente todos os passos de uma pesquisa. Dizem respeito "[...] à participação em situações de leitura/escuta, produção oral/escrita de textos que possibilitem conhecer os gêneros, a linguagem e as práticas relacionadas ao estudo e à pesquisa que favoreçam a aprendizagem dentro e fora da escola" (BRASIL, 2015, p. 75). Está relacionado à redação que prima por uma escrita mais técnica e objetiva e pela relevância da marcação das vozes no processo comunicativo, sendo que essas, entre outras características, diferenciam, desse modo, o letramento das práticas investigativas de outros campos citados anteriormente.

O documento BNCC (BRASIL, 2015, p. 75) indica que as práticas investigativas se iniciam pela inserção do estudante na atividade de leitura em que, por meio das estratégias e técnicas de leitura de "gêneros relacionados à produção de conhecimento" 11 , ele aprende a "[...] reconhecer as formas de organização e os recursos linguísticos, considerando a organização dos tópicos (do geral para o particular, do particular para o geral etc.)”. Como exemplos desses gêneros pode-se citar o projeto, o relatório, o trabalho acadêmico, o artigo etc., bem como gêneros/veículos mais contemporâneos, a exemplo dos wikis, e-book etc. Em acréscimo, a atividade de leitura desses textos deve auxiliar o estudante a "[...] identificar elementos de normatização (tais como as regras de inclusão de citações e paráfrases, de organização de referências bibliográficas) [...] e refletir sobre a intertextualidade e a retextualização nesses textos" (BRASIL, 2015, p. 77). Vê-se que a recepção desses textos permite que o estudante se torne consciente dos diferentes elementos que os compõem, bem como da função de cada elemento para a construção do sentido, sendo assim o primeiro passo para a produção desses e de outros textos.

A atividade de produção deve iniciar, ainda segundo o mesmo documento, por “[...] sínteses, com reflexões próprias, por exemplo, em anotações de aulas, palestras, seminários, reuniões" (BRASIL, 2015, p. 77), bem como filmes, documentários, diferentes gêneros discursivos/textuais, como já tratado no parágrafo anterior, cuja materialidade se concretiza pelo texto tomada de notas ou fichamento. De acordo com Valer (2016a), essa atividade é relevante para o aprendiz quando são trabalhadas, especialmente, as técnicas e as estratégias de leitura (compreensão textual, recuperação de referentes, inferenciação, interpretação e avaliação). Essas estratégias, elaboradas pelo Programa Internacional de Avaliação de Estudantes PISA (abreviatura do inglês: Programme for International Student Assessment), são usadas nos testes nacionais e internacionais dos estudantes brasileiros para medir a habilidade de leitura e escrita. Nesse processo, destaca-se, entre os aspectos, o mapa conceitual, de forma a transpor o conhecimento adquirido na leitura/escuta para a escrita. Nessa atividade, o estudante aprende a desenvolver os conceitos destacados na leitura em tópico

\footnotetext{
${ }^{11}$ Com base neste documento, dividem-se os gêneros que orientam as práticas investigativas em dois grupos: a) didáticos (tomadas de notas, resumos, ensaios, resenhas, roteiros para seminário, técnica do seminário etc.); b) científicos, os que envolvem a produção e a divulgação de conhecimento/pesquisa (projeto, relatório, trabalho acadêmico, artigo etc.).
} 
frasal, ampliando-o por meio da retextualização das respostas para as perguntas O quêe? Para quê? Por quê? Quem? Quando? Como? Onde? Quais, entre outros aspectos conforme as estratégias de leitura. Esse conteúdo parafraseado deve ser organizado em períodos em que as relações lógicas são expressas pelos diferentes elementos de coesão, de tal forma que o conteúdo relativo ao tópico frasal forme um parágrafo devidamente estruturado. Esses saberes são, portanto, a base para o aprendizado do letramento em estudo.

Ainda nessa atividade, o estudante aprende a destacar citações diretas e a compreender a sua função em relação à paráfrase, bem como o significado de plágio no processo de escrita. Na sequência, em forma de comentários, desenvolve domínios cognitivos como avaliar, justificar, relacionar o conteúdo em relação à realidade em que está inserido. Nessa prática, inicia o entendimento para o uso das diferentes vozes por meio de paráfrase, citação direta e comentário, em que diferentes expressões linguísticas precisam ser acionadas para a construção do sentido do texto. Esse aprendizado é significativo (VALER, 2016a), tendo em vista a dificuldade inicial que o estudante apresenta em separar o conteúdo pertencente a cada voz ${ }^{12}$, bem como na seleção adequada dos elementos de coesão para organizar o pensamento na modalidade escrita. Esses aspectos textuais e linguísticos são, dessa maneira, basilares para a qualificação do estudante no letramento relativo às práticas investigativas.

Após o aprendizado de tomar nota de forma sistematizada/fichamento, o estudante está preparado para “[...] produzir resumos de textos didáticos e de divulgação científica reconhecendo as características típicas do gênero resumo, compreendendo que o resumo, além de diversos usos sociais, é uma estratégia de leitura e de estudo" (BRASIL, 2016, p. 75). Nessa atividade, o estudante aprende sobre os aspectos que organizam o elemento introdução; retoma o conteúdo da tomada de nota, organizando o parágrafo de tal forma que a citação direta esteja inserida na paráfrase para dar-lhe comprovação científica; promove a progressão do tema e do texto por meio dos elementos encadeadores de parágrafos. Esses aspectos vão ampliando, desse modo, o conhecimento do conteúdo em estudo, bem como a estruturação da escrita.

A elaboração de resumo contribui em grande escala para a escrita de outros textos das práticas investigativas, como a técnica seminário, roteiro, diferentes tipos de ensaios, resenha crítica etc. A aprendizagem desses textos fornece as bases necessárias ao planejamento da atividade de pesquisa. Nessa proposta, o aprendiz deve ser ensinado a "[...] reconhecer as características típicas do gênero projeto de pesquisa, sendo capaz de desenvolver projeto que contemple atividades como levantamento de fontes de conhecimento [preparando-o para] o relatório e análise dos resultados" (BRASIL, 2015, p. 80). Dentro dessa mesma atividade, deve saber "[...] produzir diários de campo, [relatório], (registro do percurso de um trabalho de pesquisa), que auxiliem a identificar um objeto de pesquisa, as questões que devem ser respondidas, bem como fontes de conhecimento” (p. 77). Essas práticas são materializadas, de acordo com Valer (2016b), por meio do texto projeto e respectivamente pelo texto relatório ou trabalho acadêmico por terem como função planejar, registrar e avaliar os resultados, levando em conta os procedimentos que envolvem uma ação científica. Cada um desses textos é composto por elementos pré-textuais, textuais e pós-textuais específicos, em que cada elemento assume uma função particular para a construção do sentido de todo o texto, conforme a respectiva norma apresentada pela Associação Brasileira de Normas Técnicas ${ }^{13}$. Assim, a partir desses textos, a atividade da pesquisa se concretiza por meio da linguagem.

Após o aprendizado desses textos que organizam a pesquisa, os estudantes devem ser ensinados a produzir “[...] textos voltados para a divulgação do conhecimento, reconhecendo traços da linguagem desses textos (uso de vocabulário técnico/especializado, registro formal de linguagem, efeito discursivo de objetividade, recurso à citação), compreendendo e fazendo uso consciente das estratégias de impessoalização da linguagem. "(BRASIL, 2015, p. 80, grifos nossos)

\footnotetext{
${ }^{12}$ A consciência do estudante para o uso das diferentes formas de marcar as diferentes vozes no texto é um dos aspectos mais relevantes no aprendizado, não só para a construção do sentido do texto, mas também por uma questão de ética, já que ninguém pode se apropriar do patrimônio intelectual alheio, ato esse que, além de ser antiético, é ilegal pela lei dos direitos autorais: Lei n ${ }^{\circ}$ 9.610, de 19.02.1998.

${ }^{13}$ Para a teoria bakhtiniana (BAKHTIN, 1981, 2003), os gêneros são relativamente estáveis, sendo que, em determinados contextos discursivos, eles são mais que outros, como é o caso da esfera científica (ABNT) e da esfera pública (Manual da Presidência da República). Nesses contextos, o próprio órgão normatizador lança as modificações das normas em decorrência das mudanças sociais. No processo de ensino desses gêneros normatizados, o estudante precisa tomar consciência da respectiva norma, pois, nos testes e nos concursos em que esses textos são solicitados, há sempre a indicação do órgão e da norma respectivamente que o normatiza. Assim, a instituição de ensino não pode se eximir da responsabilidade de inserir o aluno no respectivo conhecimento.
} 
Essa prática se materializa, tradicionalmente, por meio do artigo científico, podendo também os resultados serem divulgados por capítulos de livros, páginas online etc. Nesses textos são mostrados como os elementos da pesquisa (tema, objeto, problema, hipótese(s), justificativa, referencial teórico, metodologia, resultados e análise) se entrelaçam, para promover no estudante as habilidades cognitivas para observar, descrever, diagnosticar, intervir, criticar, transformar etc. aspectos da realidade em um determinado tempo, espaço e cultura. Esse saber é, portanto, fundamental para o desenvolvimento do esquema cognitivo que envolve a atividade de pesquisa.

Por fim, após a sistematização de todos os passos da pesquisa, o documento coloca que é relevante que o estudante aprenda a “[...] produzir roteiros para exposição oral de resultados de estudos e pesquisas em seminários, feiras de ciências e outros eventos escolares e acadêmicos, bem como avaliar a atuação nas exposições orais próprias e dos/das colegas" (BRASIL, 2015, p. 75). Isso porque o aprendiz deve ser capaz de produzir conhecimento, bem como de avaliar o conhecimento produzido, seja dele próprio ou do outro. Em consequência desse propósito, ele deve ser inserido, assim, no letramento das práticas investigativas o mais cedo possível no processo de escolarização, sempre adequadamente mediado pelo outro.

Observa-se, em síntese, que as práticas investigativas no processo de escolarização estão relacionadas à inserção do estudante nos gêneros didáticos e científicos, que materializam a atividade social da pesquisa e todo o processo de aprendizagem que a envolve. Essas práticas estão relacionadas às práticas da cultura da informação e comunicação a fim de que a pesquisa, a escrita e a divulgação do conhecimento possam ocorrer de forma mais eficaz. Esses saberes são a base para promover no estudante o seu desenvolvimento humano, a prática da cidadania e a aprendizagem profissional.

\section{METODOLOGIA}

A investigação tomou como modalidade principal o estudo de caso simplificado, já que foram estudadas e destacadas variáveis que direcionam uma atividade social na área educacional, sendo que os dados coletados serão aplicados no ensino da educação profissional (SEVERINO, 2007). Quanto à natureza e coleta de dados, a pesquisa secundária em destaque foi a documental, pois foram analisados dois documentos oficiais no decorrer da pesquisa.

As variáveis de análise nesta pesquisa são constituídas por alguns dos princípios educativos que norteiam o processo de ensino e aprendizagem da Educação Profissional Técnica de Nível Médio. São elas:

a) os elementos da pesquisa como princípio pedagógico: identificação de uma dúvida ou problema, seleção de informações de fontes confiáveis, interpretação e elaboração dessas informações, organização e relato sobre o conhecimento adquirido;

b) as tecnologias digitais como ferramenta de leitura, escrita e socialização da informação: Facebook, Google+ etc., com 76\% do total de usuários. Além dessas, ainda aparecem no relatório outras TIC de compartilhamento de textos, imagens e vídeos, como email, blogs, wikis, portais de notícias, fotologs, radioblogs, videologs, provedores de filmes via streaming;

c) os gêneros textuais relativos às práticas investigativas: estratégias de leituras de textos didáticos e científicos; sínteses com reflexões próprias, por exemplo, em anotações de aulas, palestras, seminários, reuniões etc.; resumos de textos didáticos e de divulgação científica; projeto, relatório e textos de divulgação científica.

Essas variáveis foram extraídas de dois documentos do Ministério da Educação, os quais apresentamos a seguir:

O documento Diretrizes Curriculares Nacionais Gerais da Educação Básica, lançado em 2013, compila um trabalho de amplo debate nas diversas instâncias de ensino ocorrido desde 2006. Tem por meta prover os sistemas educativos em seus vários níveis (municipal, estadual e federal) de princípios educativos para que crianças, adolescentes, jovens e adultos, "[...] possam se desenvolver plenamente, recebendo uma formação de qualidade correspondente à sua idade e nível de aprendizagem, respeitando suas 
diferentes condições sociais, culturais, emocionais, físicas e étnicas” (p. 6). Para esse propósito, o documento apresenta as diretrizes da Educação Infantil, Fundamental e Média e acrescenta as diretrizes para a Educação no Campo, a Educação Indígena, a Quilombola, a Educação Especial, a de Jovens e Adultos em Situação de Privação de Liberdade nos estabelecimentos penais e para a Educação Profissional Técnica de Nível Médio. Amplia com as diretrizes para a Educação de Jovens e Adultos, a Educação Ambiental, a Educação em Direitos Humanos e para a Educação das Relações Étnico-Raciais e para o Ensino de História e Cultura Afro-Brasileira e Africana ${ }^{14}$.

A Base Nacional Comum Curricular (BNCC) tem seus princípios fundamentados para atender o Plano Nacional de Educação (PNE) e as Diretrizes Curriculares Nacionais Gerais para a Educação Básica, constituída pela Educação Infantil, Ensino Fundamental e Ensino Médio. Esse documento foi construído por profissionais de diferentes instituições de ensino, públicas e privadas, ao longo de 2014, sendo que, em 2015, foi submetido à ampla consulta pública para debate e contribuições das diversas instâncias sociais, para posterior submissão ao Conselho Nacional de Educação. O objetivo do documento é sinalizar percursos de aprendizagem e desenvolvimento capazes de garantir, aos sujeitos da Educação Básica, o acesso-permanência-sucesso-progressão nos estudos, dando-lhes condições para ingressarem no ensino superior.

Este artigo é produto de um projeto institucional para reforço dos grupos de pesquisa, entre os quais está o grupo Língua(gem) e Comunicação (CNPQ), do Instituto Federal de Educação, Ciência e Tecnologia de Santa Catarina, do Campus FlorianópolisContinente. O grupo foi criado em 2013, com o objetivo de firmar discussões e unir as pesquisas desenvolvidas pelos docentes da área. Assim, as autoras deste artigo fazem parte desse grupo de pesquisa, embora outros docentes do grupo também tenham participado em algum momento das discussões sobre o tema em análise.

A partir dos resultados encontrados, pretende-se promover discussões internas com o propósito de pensar procedimentos eficazes para a qualificação do ensino e da aprendizagem em relação ao objeto em estudo em cada componente, bem como o objeto de cada curso. Pretende-se também divulgar os dados através de publicação científica e em eventos da área de Linguagem que tenham como escopo questões relacionadas ao ensino de linguagem na Educação Profissional.

\section{ANÁLISE E DISCUSSÃO}

Este artigo tem como objeto de estudo a pesquisa como princípio pedagógico e como objetivo geral mapear quais gêneros discursivos/textuais materializam todo o processo que envolve essa atividade. Ao se analisar os documentos que atualizam os objetivos da Educação Básica e ampliam as diretrizes para que as instituições de ensino logrem uma melhor qualidade educativa, vê-se que esse princípio pedagógico, tradicionalmente aplicado de uma forma mais ampla na esfera acadêmica, ou seja, na educação superior, necessita ser adotado na esfera escolar. Nessa proposta, os gêneros que orientam o trabalho didático-pedagógico nas práticas investigativas para a formação geral na esfera escolar devem também ser adotados na educação profissional, em todos os níveis e modalidades, de forma progressiva e mediada por toda a comunidade escolar, conforme está sendo discutido ao longo deste texto.

No contexto educacional, o termo pesquisa é tomado muitas vezes como a prática de consulta de fontes sobre determinado tema, gerando a pesquisa bibliográfica. Em outras situações, esse termo é utilizado para designar apenas a ação de coletas de dados em determinado contexto social. Essas duas ações são pertinentes ao processo, porém, ao tratar-se do termo pesquisa como está posto acima (BRASIL, 2013), entende-se que essa atividade é uma ação bem mais complexa, necessitando, portanto, de uma atenção mais bem planejada por parte dos envolvidos na atividade pedagógica.

Esse princípio pedagógico, inserido em um tema de estudo, deve desenvolver no aprendiz a prática para "a identificação de uma dúvida ou problema”, que pode ser de ordem pessoal, profissional, social etc. (BRASIL, 2013). Através desse princípio, o estudante

\footnotetext{
${ }^{14}$ Está em processo, desde setembro de 2016, quando foi apresentada, a Medida Provisória n, 746, que propõe mudanças substanciais aos atuais documentos que institucionalizam o Ensino Médio, dentre eles, os discutidos aqui.
} 
deve ser ensinado a selecionar "fontes confiáveis" de informações sobre o tema, para que ele próprio as leia e as interprete; a tomar consciência da função de cada passo dessa atividade a fim de aprender a delimitar o objeto, definir o "problema” e criar as hipóteses (se houver) para o problema identificado, bem como a elaborar o objetivo, a justificativa, o referencial teórico do objeto em estudo e a metodologia da pesquisa. Após a elaboração do projeto, inicia-se o desenvolvimento da atividade planejada, e o "relato" ocorre paralelamente e após o processo de pesquisa/atividade/ação, em que são descritos os resultados encontrados, desencadeando na discussão "do conhecimento adquirido" desde o planejamento da pesquisa até a sua finalização. Vê-se que essa atividade é constituída de diversos passos, exigindo, dessa forma, que o processo de ensino seja bem elaborado e mediado a fim de que ocorra a efetiva aprendizagem.

Essa atividade não deve ser encerrada sem que haja uma análise profunda entre a teoria sistematizada e os dados encontrados, isso porque o desenvolvimento dessa prática pode, ao longo da vida, desenvolver, no indivíduo, condições para “[...] interpretar, analisar, criticar, refletir, rejeitar ideias fechadas, aprender, buscar soluções e propor alternativas, potencializadas pela investigação e pela responsabilidade ética assumida diante das questões políticas, sociais, culturais e econômicas” (BRASIL, 2013, p. 218).

Isso a fim de que o estudante consiga refletir a sua realidade, repensá-la, propor mudanças, criar possibilidades de agir sobre essa realidade ou, se for o caso, discutir a própria teoria, focalizando sempre os princípios da ciência, da tecnologia, do trabalho e da cultura, gerando, assim, um olhar mais crítico em relação ao espaço que o envolve.

Esse princípio pedagógico deve ser assumido por toda a comunidade escolar, preferencialmente por meio de projetos ou atividades com abordagens disciplinar, pluridisciplinar, interdisciplinar e transdisciplinar, "[...] porque revelam a visão de mundo que orienta as práticas pedagógicas dos/as educadores/as e organizam o trabalho do/a estudante” (BRASIL, 2013, p. 27). Essa prática pedagógica contribui para que o estudante desenvolva uma visão mais alargada do objeto de estudo com o qual ele está envolvido, e não mais pelo viés da fragmentação do aprendizado comumente realizado na escolarização. Ressalta-se que esse procedimento de ensino propõe uma nova forma de aprendizado, ressignificando, dessa maneira, o próprio tempo e espaço do contexto escolar.

A materialização da atividade de pesquisa, como está apresentada acima (BRASIL, 2015, p. 80-85), ocorre por práticas específicas de linguagem, compreendidas por gêneros discursivos/textuais, objeto de ensino da área de Línguas. Esse processo progressivo de aprendizagem se inicia pela leitura de textos com foco nos conceitos teóricos do objeto em estudo e segue para a escrita. A produção inicia-se pela elaboração de tomadas de notas/fichamento, podendo abarcar gêneros como resumos, diferentes ensaios, projetos de pesquisa, relatórios, trabalhos acadêmicos e textos de divulgação da respectiva pesquisa. Textos orais como seminário, mesa redonda, palestra, painel, entre outros, também fazem parte desse letramento, sempre guiados por textos escritos como, por exemplo, o roteiro de apresentação oral ou slides. Cada um desses textos apresenta uma função social específica e, ao serem adotados no processo de escolarização, desenvolvem no estudante habilidades cognitivas e linguísticas específicas. Todas essas ações qualificam, portanto, o processo de aprendizagem do letramento relacionado às práticas investigativas.

Na contemporaneidade, com o advento das Novas Tecnologias de Inovação e Comunicação (TIC), a produção dos gêneros discursivos/textuais passou por uma grande mudança. As normas técnicas da ABNT são inclusive um reflexo dessas mudanças, à medida em que, na atualidade, determinam a formatação dos gêneros didáticos e científicos em meio digital. Conforme esclarece Rojo (2013, p. 8), "[...] se os textos da contemporaneidade mudaram, as competências/capacidades de leitura e produção de textos exigidas para participar de práticas de letramento atuais não podem ser as mesmas”. Está posto para os professores de línguas o desafio de auxiliar os aprendizes no desenvolvimento dos novos letramentos. Para isso, devem desbravar com os estudantes, além das estratégias e práticas complexas de leitura e escrita já discutidas anteriormente, também aquelas relacionadas ao ciberespaço, especialmente com os excluídos digitais já em suas práticas cotidianas. Esses aspectos apontam, dessa forma, para novos procedimentos pedagógicos no processo de escolarização.

Os gêneros relativos às práticas investigativas são, na maioria das vezes, solicitados e produzidos em meio digital, principalmente porque a divulgação científica se dá cada vez mais online, por meio de revistas científicas digitais e inclusive por e-books. Torna-se, então, responsabilidade das instituições de ensino, incluindo as que formam estudantes para o trabalho, promover o desenvolvimento de habilidades como letramento colaborativo/participativo e multiletramentos. Cabe a essas instituições, e

Forum linguistic., Florianópolis, v.14, n.4, p. $2785-2803$, out./dez. 2017 . 
particularmente aos professores de línguas tratar das especificidades desses gêneros como objeto de ensino, ampliando a todos o acesso e a utilização das TIC enquanto ferramentas de produção dos gêneros discursivos que materializam os processos de pesquisa, qualificando, assim, a educação como um todo.

No contexto educacional de educação profissional em que esta pesquisa se realiza, trabalha-se com dois cursos superiores, com cursos de Formação Inicial e Continuada (FIC) e com um curso técnico integrado ao Ensino Médio na modalidade Educação de Jovens e Adultos (PROEJA), além de cursos técnicos subsequentes, carros-chefes do campus Florianópolis-Continente. Em relação ao problema de pesquisa, destaca-se que a Resolução N. 6, de 20 de setembro de 2012 (BRASIL, 2012), que trata da oferta da Educação Profissional Técnica de Nível Médio, no Capítulo I, Art. 9, alerta que na oferta de "cursos na forma subsequente, caso o diagnóstico avaliativo evidencie necessidade, devem ser introduzidos conhecimentos e habilidades inerentes à Educação Básica, para complementação e atualização de estudos”. Entende-se que o documento ressalta a necessidade de se diagnosticar o nível de letramento do estudante que adentra essa modalidade de educação, a fim de que se assegure, desse modo, que ele consiga acompanhar o processo educativo com qualidade para o sucesso e a progressão.

Ao tratar-se dos sujeitos estudantes dos cursos técnicos subsequentes do campus Florianópolis-Continente, observa-se que as turmas são constituídas de forma bastante heterogênea: graduados recentes, graduados há mais tempo, com Ensino Médio recémfinalizado e Ensino Médio concluído há bastante tempo sem terem progredido nos estudos. Sendo a finalidade da instituição a inclusão social, a forma de seleção permite o ingresso de muitos estudantes com déficit de letramento, especialmente do letramento das práticas investigativas e do uso da tecnologia de informação e comunicação para esse fim.

Em decorrência dessa realidade, na prática pedagógica do componente curricular de Linguagem (língua materna), destaca-se no plano de aula um percentual de $25 \%$ da carga horária para iniciar os estudantes nesse letramento. O restante da carga horária é dedicado ao ensino dos gêneros discursivo/textuais voltados ao campo do trabalho, os quais incluem a redação técnica e os textos orais e escritos para fins específicos do espaço profissional de cada. Para dar conta do propósito, selecionaram-se como recurso didático-pedagógico diferentes gêneros textuais (didáticos, científicos, jornalísticos etc.), os quais tratam de diferentes conceitos teóricos sobre comunicação não-verbal, oral e escrita. A atividade proposta prima pela qualidade, em que a teoria embasa a prática (simulação de situações reais de comunicação, práticas de comunicação no contexto escolar e profissional, projeto de visita técnica, projeto de estágio, projeto de pesquisa-ação etc.) e a reflexão sobre a prática pela observação, descrição e avaliação dos aspectos que caracterizam as formas de comunicação em diferentes contextos de comunicação.

Aqui se aponta para um problema recorrente nas respectivas aulas. Quando os estudantes são inseridos nas estratégias de leitura e na escrita dos respectivos textos, muitos consideram essa prática muito difícil e desnecessária ao curso técnico. Alegam ser um conhecimento que eles não usarão no seu contexto profissional, ou ainda que esse conhecimento só deve ser aprendido no ensino superior para fazer o TCC. A prática de reescrita dos textos também causa a eles estranhamento, justificam que isso lhes ocupa muito tempo por envolver muitos aspectos para a qualidade da escrita, entre os quais está a dificuldade em usar a tecnologia digital para esse fim. Essas colocações baseadas no senso comum e na própria experiência de escolarização refletem, de alguma forma, que essa prática pedagógica ainda não é adotada pelos demais docentes da comunidade escolar em que ainda predominam aulas expositivas e avaliações, em que aspectos relevantes da linguagem são desconsiderados na textualização das diferentes finalidades discursivas, como, por exemplo, a marcação das diferentes vozes e respectivas referências para a construção do sentido da textualização, entre outros aspectos.

No Campus Florianópolis-Continente, local desta pesquisa, o ensino e a aprendizagem de línguas adicionais ocorre nos idiomas Inglês e Espanhol. Em decorrência da carga horária reduzida, tem-se dado prioridade, nos componentes curriculares de Inglês, para as estratégias de compreensão escrita (leitura superficial, leitura detalhada, identificação de palavras cognatas, evidências tipográficas, inferência, conhecimento prévio etc.). Além de atividades de compreensão oral, pois atividades envolvendo tais habilidades receptivas podem ser desenvolvidas em menor espaço de tempo, proporcionando assim maior estímulo aos estudantes em termos de aquisição de competências. Os gêneros textuais explorados são voltados basicamente para a área dos cursos profissionalizantes ofertados pelo campus Florianópolis-Continente: Turismo, Hospitalidade e Lazer. Assim, por exemplo, a partir de visitas técnicas os estudantes são expostos a relatos orais de profissionais da área para fazerem tomadas de notas e resumos 
posteriormente.

Já nos componentes curriculares de Espanhol, devido a essa ser uma língua cada vez mais presente nas práticas sociais nas quais estudantes brasileiros e, principalmente, catarinenses se envolvem, é possível propor com maior frequência também a produção de gêneros escritos. Nesses componentes, o trabalho com gêneros como tomada de notas e resumos simplificados costuma desencadear gêneros de divulgação relacionados às áreas profissionais como relatos de experiência técnica, folheteria, páginas digitais de divulgação, entre outros.

Observa-se que esse letramento costuma abarcar variadas estratégias de leitura, assim como de escuta de textos audiovisuais, em se tratando do desenvolvimento de habilidades de recepção escrita e oral de textos. No que diz respeito à produção escrita, as práticas normalmente restringem-se, em decorrência dos diversos níveis de proficiência dos alunos, ao trabalho com gêneros mais curtos, como tomada de notas e resumos simplificados, ou seja, sem levar em consideração determinados aspectos composicionais e estilísticos definidos no referencial teórico. Em muitos casos essas produções investigativas sustentam produções textuais voltadas para a área de formação profissional, sendo esses textos produzidos em meios digitais e permeados por práticas interdisciplinares em parceria com professores das áreas técnicas.

Em síntese, ao se analisar as práticas de letramento nos componentes de Línguas Adicionais, percebe-se que, devido primordialmente a questões relacionadas à carga horária reduzida e à proficiência dos alunos nas línguas, tais práticas não contemplam a complexidade que envolve o letramento proposto nos documentos estudados. Outro aspecto demonstrado na análise é que, apesar dos componentes de Línguas Adicionais terem um histórico de interdisciplinaridade, percebe-se que é possível qualificar a parceria entre os componentes de Línguas Adicionais e Português, no sentido de compartilhar os gêneros como unidades de ensino para potencializar as práticas discursivas em estudo.

As colocações acima parecem comprovar o pressuposto de pesquisa de que há a necessidade de um entendimento mais amplo entre o conceito de pesquisa e o letramento adequado no processo de escolarização para esse fim. Os documentos norteadores para a educação de qualidade, com base nos atuais pressupostos teóricos, indicam que o objeto de ensino privilegiado da língua são "[...] os textos como materialidade de gêneros discursivos, à luz das diferentes dimensões pelas quais eles se constituem. (BRASIL, 2006, p. 36). O processo de escolarização é o espaço em que os estudantes devem ser inseridos nesses diferentes processos comunicativos, haja vista que muitos deles não têm acesso a esses usos sociais da linguagem além do espaço escolar. Essa realidade exige, dessa forma, uma ação mais ampla em relação a esses indivíduos no processo de escolarização.

Sabe-se que o conhecimento próprio do conteúdo das línguas está para além delas, pois, pela interação verbal, deve permitir o desenvolvimento das habilidades linguísticas dos alunos, para que em todos os contextos os sujeitos sejam aptos a "Informar e informar-se, comunicar-se, expressar-se, argumentar logicamente, aceitar ou rejeitar argumentos, manifestar preferências, apontar contradições, fazer uso adequado de diferentes nomenclaturas, de diferentes códigos e de diferentes meios de comunicação." (BRASIL, 2002, p. 13).

Nessa proposta educacional, os gêneros textuais, unidade de ensino da língua, podem ser utilizados, por exemplo, como recursos pedagógicos no processo de avaliação de conhecimento pelos demais docentes em seus componentes curriculares e não somente pelos professores de Línguas, desencadeando, portanto, um processo de aprendizado mais significativo para os estudantes.

Essa ação pedagógica deve assumir relevância no processo de escolarização por todos os docentes, isso porque essa prática envolve "[... a aprendizagem como processo de apropriação significativa dos conhecimentos, superando a aprendizagem limitada à memorização" (BRASIL, 2013. p.219). Essa forma de letramento em que ocorre a "[...] articulação teoria e prática, vinculando o trabalho intelectual às atividades práticas ou experimentais [...]” (p.219), quando efetivamente incorporada à linguagem dos estudantes ao longo do processo de escolarização, dá-lhe as condições para a permanência, o sucesso e a progressão, efetivando, dessa forma, a qualidade da educação. 
Em decorrência desses aspectos, ressalta-se o cuidado que se deve ter para que atividades cognitivas complexas ${ }^{15}$ que se constituem por processos complexos de linguagem não sejam simplificadas no decorrer da escolarização. Ressalta-se que "A escola não pode garantir o uso da linguagem fora do seu espaço, mas deve garantir tal exercício de uso amplo no seu espaço, como forma de instrumentalizar o aluno para o seu desempenho social. Armá-lo para poder competir em situação de igualdade com aqueles que julgam ter o domínio social da língua.” (BRASIL, 2000, p. 22).

Esse saber muitas vezes pode deixar de ser ensinado pela crença de que estudantes com déficit de letramento não sejam capazes de aprendizagem; pela falta de tempo para trabalhar com esses textos; para evitar as reclamações dos estudantes, ou ainda pelo entendimento de que esses sujeitos não farão uso dessa linguagem no contexto profissional ou no seu cotidiano etc. Essas ações contradizem, assim, o papel da comunidade escolar, que deve, em conjunto, encontrar procedimentos pedagógicos adequados para superar os déficits diagnosticados nos estudantes quando adentram na instituição de ensino.

Dentro dessa perspectiva, de acordo com Moll et al. (2010), muitos servidores do IFSC, através de pesquisas e da representação sindical, vêm lutando e defendendo o ideal de universalização da Educação Básica de qualidade, em oposição à forte adesão à doutrina neoliberal mais acentuada nos governos dos anos 1990. Com base no exposto,

Restaria perguntar, portanto, a quem interessa reduzir a formação ao conhecimento tácito por uma epistemologia na qual a prática se constrói pela reflexão sobre si mesma, sem a mediação da teoria, desqualificando-se os espaços onde os que vivem do trabalho poderiam ter acesso ao conhecimento científico, tecnológico e sócio-histórico, como produto do pensamento humano (MOLL et al., 2010, p. 267).

Ressalta-se que, para que se efetive o trabalho com a pesquisa como princípio pedagógico, os componentes curriculares da área de Linguagens precisam tomar para si a responsabilidade de trabalhar com esse letramento, além do letramento do campo profissional, para que os respectivos gêneros discursivos/textuais sirvam de recursos didático-pedagógicos no processo de escolarização da Educação Profissional Técnica de Nível Médio.

\section{CONSIDERAÇÕES FINAIS}

O objetivo desta pesquisa foi o de compreender melhor o conceito de pesquisa como princípio pedagógico no processo de escolarização e de que forma os componentes curriculares de Línguas participam desse processo, já que a pesquisa se concretiza por meio de gêneros textuais específicos. Para dar conta desse propósito, foram lidos e discutidos os documentos oficiais que colocam as diretrizes para a Educação Básica e Profissional, bem como teóricos da Linguística (Teórica, Aplicada, Psicolinguística etc.) e da área da Educação.

Ao se analisar as variáveis destacadas, relacionando-as ao referencial teórico, e se discutir as práticas de letramento na instituição em que a pesquisa foi realizada, os resultados encontrados indicam que se faz necessária uma ampla discussão entre todos os atores envolvidos no processo educacional do que seja a pesquisa como princípio pedagógico em termos de atividade social que se materializa por meio da linguagem, tornando-se objeto de ensino e aprendizagem na esfera escolar. Conclui-se que o letramento das práticas investigativas e das práticas tecnológicas de informação e comunicação que concretizam a pesquisa como princípio pedagógico deve ser utilizado como recurso didático-pedagógico nos diferentes componentes curriculares, independentemente do nível de letramento do estudante que adentra na instituição.

Os procedimentos metodológicos que envolvem esse aprendizado devem ser discutidos e assumidos por toda a comunidade escolar, de tal forma que o estudante seja progressivamente inserido nesse conhecimento e aproveite o tempo de escolarização para esse fim.

\footnotetext{
${ }^{15}$ Destaca-se, nesse processo, os pressupostos teóricos da Psicolinguística relativos aos aspectos linguísticos e epilinguísticos, além da relevância da metalinguagem e da consciência metatextual (GOMBERT, 1992, 1993, 2003) para o desenvolvimento dos processos comunicativos mais complexos necessários ao desenvolvimento de esquemas cognitivos mais abrangentes para a formação do sujeito social e profissional.
} 
Em outras palavras, a sistematização das teorias do objeto de estudo, a realidade (observação, simulação ou prática) em que o objeto se insere e a reflexão teórica sobre a realidade devem ser o propósito educativo na escolarização. Esses procedimentos oferecem ao estudante as condições de interpretar, analisar, criticar, refletir, rejeitar ideias fechadas, aprender, buscar soluções e propor alternativas.

Assim, criam-se perspectivas para a formação de um sujeito crítico e ético, capaz de intervir sobre a realidade em relação às questões políticas, sociais, culturais e econômicas, recriando-a de tal forma a auxiliar na construção de uma sociedade mais justa e fraterna. Com essa prática educativa e pedagógica, as habilidades cognitivas e linguísticas poderão ser ampliadas de forma significativa, sendo que esses saberes contribuem de forma plena para a permanência, o sucesso e a progressão de todos os estudantes em todas as modalidades e níveis da Educação Básica, concretizando, assim, uma educação inclusiva, politécnica e universal.

\section{REFERÊNCIAS}

BAKHTIN, M. Problemas da poética de Dostoiévski. Tradução Paulo Bezerra. Rio de Janeiro: Forense Universitária, 1981. [1929].

. Estética da criação verbal. 3. ed. São Paulo: Martins Fontes, 2003. [1930].

BRASIL. Constituição da República Federativa do Brasil: promulgada em 5 de outubro de 1988. Disponível em: <www.planalto.gov.br/ccivil_03/constituicao/constituicao.htm>. Acesso em: 20 fev. 2014.

BRASIL. Lei no 9.394, de 20 de dezembro de 1996. Estabelece as diretrizes e bases da educação nacional. Diário Oficial da União, Brasília, DF, 23 de dez. 1996. Disponível em: < portal.mec.gov.br/arquivos/pdf/ldb >. Acesso em: 10 mar. 2014.

BRASIL. Parâmetros Curriculares nacionais. Ensino Médio: Parte II - Linguagens, códigos e suas tecnologias. Brasília: MEC/SEF, 2000. Disponível em: <portal.mec.gov.br/seb/arquivos/pdf/linguagens02.pd>. Acesso em: 30 mar. 2014.

BRASIL. Orientações Educacionais Complementares aos Parâmetros Curriculares Nacionais. Linguagens, Códigos e suas Tecnologias. Brasília: MEC/SEF, 2002. Disponível em: <portal.mec.gov.br/seb/arquivos/pdf/linguagens02.pdf>. Acesso em: 30 mar. 2014.

BRASIL. Orientações curriculares para o ensino médio. Volume 1: Linguagens, códigos e suas tecnologias. Brasília: MEC/SEF, 2006. Disponível em: <portal.mec.gov.br/seb/arquivos/pdf/book_volume_01_internet.pdf>. Acesso em: 30 mar. 2014.

BRASIL. Câmara de Educação Básica. Resolução n. 6, de 20 de Setembro de 2012. Define Diretrizes Curriculares Nacionais para a Educação Profissional Técnica de Nível Médio. Disponível em: <mobile.cnte.org.br:8080/legislação-externo/rest. /Lei/51/p.f.>. Acesso em: 20 fev. 2014.

BRASIL. Catálogo Nacional dos Cursos Técnicos. Brasília: MEC/SISTEC, 2012. Disponível em: <portal.mec.gov.br/index.php? option=com_docman\&task >. Acesso em: 30 mar. 2014.

BRASIL. Diretrizes Curriculares Nacionais Gerais da Educação Básica. Brasília: MEC/SEB/DICEI, 2013. Disponível em:< file://C:/Users/User/Downloads/diretrizes_curiculares_nacionais_2013\%20(3).pdf>. Acesso em: 10 mar. 2014.

BRASIL. Base Nacional Curricular Comum: consulta pública em 2015. Brasília: MEC/SEB/DICEI, 2015. Disponível em: < basenacionalcomum.mec.gov.br/documento/BNCC-APRESENTACAO.pdf>. Acesso em: 10 out. 2015. 
CELANI, M. A. A. et al. ESP in Brazil: 25 Years of Evolution and Reflexion. São Paulo: Editora da PUC-SP, 2005.

COMITÊ GESTOR DA INTERNET NO BRASIL (CGI). Dimensões e características da web brasileira. São Paulo: CGI, 2010. Disponível em: <www.cgi.br/publicacoes/pesquisas/govbr/cgibr-nicbr-censoweb-govbr-2010.pdf>. Acesso em: 5 ago. 2016.

TIC Domicílios 2014: pesquisa sobre o uso das tecnologias de informação e comunicação nos domicílios brasileiros. São Paulo: CGI, 2015. Disponível em: <www.cgi.br/media/docs/publicacoes/2/TIC_Domicilios_2014_livro_eletronico.pdf>. Acesso em: 5 ago. 2016.

DEMO, P. Pesquisa: princípio científico e educativo. 12. ed. São Paulo: Cortez, 2006.

Educar pela pesquisa. 10. ed. Campinas, SP: Autores associados, 2015.

GARCÍA, O. Bilingual Education in the 21st Century: a Global Perspective. Malden, MA and Oxford: Basil/Blackwell, 2009.

GOMBERT, J. E. Metalinguístic development. Chicago: University of Chicago Pres, 1992.

Metacognition, metalanguage and metapragmatics. International Journal of psychology, v. 28, n.5, p. 571-580, 1993. Disponível em:

< valtweb2a.valt.helsinki.fi/blogs/harmo/meta>. Acesso em: 2 fev. 2010.

. Metalinguagem e aquisição da escrita. In: MALUF, M. R. (Org.). Aquisição da escrita: contribuições da pesquisa para a prática da alfabetização. São Paulo: Casa do Psicólogo, 2003.

MARTINS, J. S. O trabalho com projetos de pesquisa: do ensino fundamental ao ensino médio. 6. ed. Campinas: Papirus, 2009.

MOLL. J. et al. Educação profissional e tecnológica no Brasil contemporâneo: desafios, tensões e possibilidades. Porto Alegre: Artmed, 2010 .

ROJO, R. Gêneros do discurso e gêneros textuais: questões teóricas e aplicadas. In: MEURER, J. I.; BONINI, A.; MOTTA-ROTH, D. (Org.). Gêneros: teorias, métodos e debates. São Paulo: Parábola Editorial, 2005. p.184-207.

(Org.). Escola conectada: os multiletramentos e as TICs. São Paulo: Parábola, 2013.

SCHLATTER, M.; GARCEZ, P. Línguas adicionais (espanhol e inglês). In: Referenciais curriculares do Estado do Rio Grande do Sul: linguagens, códigos e suas tecnologias. Porto Alegre: SE/DP, v. 1, p. 127-172, 2009. Disponível em: $<$ http://www.educacao.rs.gov.br/pse/html/refer_curric.jsp?ACAO=acaol>. Acesso em: 14 nov. 2016.

SEVERINO, A. J. Metodologia do trabalho científico. 23. ed. São Paulo: Cortês, 2007. 
VALER, S. Produção textual: textos didáticos. Mimeo. 2016a.

Pesquisa científica: do método à divulgação. Mimeo. 2016b.

VIGOTSKI, L. S. A formação social da mente. 7. ed. São Paulo: Martins Fontes, 2008. [1930]. 